\title{
Johann Baptist Ritter von Spix: primeiro zoólogo de Munique e pesquisador no Brasil
}

\section{Johann Baptist Ritter von Spix, the first zoologist of Munich and the first researcher of Brazil}

\author{
Ernst Josef Fittkau \\ Zoólogo, doutor pela Universidade de Kiel, Alemanha \\ Zoologische Staatssammlung München \\ Munchhausenstr 21 \\ Munchen D-81247 \\ Alemanha
}

omo ex-diretor da Zoologischen Staatssammlung München, tenho particular interesse em falar sobre Johann Baptist von Spix. ${ }^{1}$

Por determinação do rei da Baviera, Maximiliano José I, Johann Baptist von Spix (1781-1826) foi contratado como zoólogo pela Academia Real de Ciências, em 31 de outubro de 1810, para organizar um museu de zoologia em Munique. Fui o décimo sucessor de Spix na direção da Zoologischen Staatssammlung München.

Quando aceitei o cargo em 1976, surpreendeu-me o fato de que várias pessoas em Munique e mesmo na Zoologischen Staatssammlung München pouco sabiam sobre Spix. Pude constatar, mais tarde, que além de uma rua chamada Martius, localizada numa conhecida e agradável parte da cidade de Munique, havia também, um pouco distante, uma pequena rua chamada Spix. Um ano depois, em 1977, tive a oportunidade de fazê-lo ser lembrado na primeira edição da Spixiana, ${ }^{2}$ uma revista especializada na publicação de trabalhos na

\footnotetext{
${ }^{1}$ Depoimento resultante de palestra proferida na Fundação Oswaldo Cruz (Fiocruz) em dezembro de 1998.

${ }^{2}$ A revista Spixiana foi criada em 1977 em homenagem a Johann Baptist von Spix, tendo como seu idealizador e editor-chefe Ernst J. Fittkau. Em 1983, foi publicado um número especial, com artigos de especialistas que participaram do simpósio ocorrido em Munique em 1981, em homenagem ao segundo centenário de nascimento de Spix.
} 
DEPOIMENTO

área de zoologia, editada pela Zoologischen Staatssammlung München. Tive nova oportunidade ao organizar um simpósio sobre Spix, quando se celebrou seu segundo centenário de nascimento, em 1981. Numa contribuição para os anais do simpósio, publicados como suplemento da Spixiana, o célebre ornitólogo Helmut Sick escreveu: "Cada vez que alguém fala sobre Spix, de imediato vê-se obrigado a defendê-lo diante de Martius, seu muito conhecido companheiro de viagem. Quem sabe algo sobre Spix?"3 Helmut Sick, que adotou o Brasil como pátria e foi pesquisador, por muitos anos, do Museu Nacional do Rio de Janeiro, expressou, com seu ponto de vista, o que Munique - a herdeira do produto do trabalho de Spix — também precisava e ainda precisa perceber.

Hoje temos um objetivo: reconstruir essa história sem equívocos ou mal-entendidos.

Nem a história da pesquisa no Brasil nem a pessoa de Spix podem ser entendidas se o seu nome é colocado à sombra do botânico Karl Friedrich Philipp von Martius (1794-1868). Na primeira edição alemã da Viagem pelo Brasil ${ }^{4}$ Martius faz uma homenagem acanhada, citações sem muita importância e reproduz uma gravura de Spix, não obstante tenha sido ele o responsável e o coordenador da expedição e ainda co-autor da publicação.

Por ocasião do centenário da morte de Martius, em 1968, foi criado o Museu Martius no Parque Nacional da Serra dos Órgãos, em Teresópolis (RJ), no antigo terreno da fazenda do barão de Langsdorff, onde Spix e Martius realizaram sua primeira incursão científica, em 1817. Foi criada também a Fundação Martius, em São Paulo, por iniciativa teuto-brasileira. A contribuição de Spix para a ciência brasileira foi consignada nesses eventos, como eu mesmo pude constatar, mas não à altura da real importância que ela teve. Seria justo desejar que, se houver uma renovação daquele museu, ele venha a se chamar Museu Spix e Martius. Tive a mesma surpresa ao visitar no Instituto Goethe, no Brasil, exposição itinerante organizada em Munique. Ela também seguia mostrando a Viagem pelo Brasil como trabalho só de Martius. Lembro ainda de um filme feito para a televisão alemã, há cerca de dois anos, sobre a viagem de Spix e Martius, intitulado A expedição de Martius.

\footnotetext{
${ }^{3}$ Helmut Sick (1910-1991) nasceu em Leipzig, Alemanha. Ornitólogo, chegou ao Brasil em 1939 como membro da expedição do Museu de Berlim chefiada por Adolf Schneider. Radicouse no país e trabalhou para a Fundação Brasil Central e, posteriormente, para o Museu Nacional do Rio de Janeiro, como pesquisador. Promovido a professor titular da Universidade do Brasil, atualmente UFRJ, e aposentou-se em 1981 (Pacheco \& Bauer, 1995). Ver também Sick (1983, pp. 29-31)

${ }^{4}$ O Reise in Brasilien... foi publicado em três partes: o primeiro volume saiu em 1823, com 412 páginas; o segundo, em 1828, estendeu-se até a página 884; e o terceiro, em 1831, totalizando 1.388 páginas. Acompanhavam um atlas e um anexo musical. A primeira tradução para o português foi promovida pelo IHGB, em comemoração ao seu centenário, e publicada pela Imprensa Nacional em 1938. Cf. von Spix \& von Martius (1823).
} 
Houve momentos em que Spix não foi esquecido. No final do século XIX, foram confeccionados em Munique dois monumentos para o parque do Museu Goeldi, em Belém, (PA): um dedicado a Martius e o outro a "Johannes de Spix ex Baviera, o qual fez-se benemérito, através de sua pesquisa sobre a fauna brasileira". A lápide de Spix, em Munique, destruída Segunda Guerra Mundial, aludia "aos restos mortais do mais sagaz, honrado e respeitável dos homens, dr. Johann von Spix, cavaleiro da Ordem do Mérito Civil, membro da Academia Real de Ciências. Ele faleceu em 13 de maio de 1826 aos 45 anos. Toda a sua vida e todas as suas forças foram dedicadas à pesquisa das formas e leis da natureza. Como nenhum outro, estudou e pesquisou as regiões do Novo Mundo, colecionou, organizou e descreveu formas representativas do clima quente. Dedicou-se, desde muito cedo, à pesquisa científica, e agora foi para um mundo melhor. Ele tornou-se imortal através de sua obra e da fundação de um museu brasileiro, monumentos que sobreviverão ao tempo."

Esse museu brasileiro colocou ao alcance do público a coleção oriunda da expedição, e o material etnológico ainda hoje nos causa admiração. Mas o museu não sobreviveu: logo depois da morte de Spix, foi fechado, destinando-se o lugar a outro objetivo. Por dez anos, o material etnológico permaneceu inacessível. Talvez por isso os objetos estejam bem conservados e ainda exista a melhor documentação do nosso tempo sobre a cultura indígena. ${ }^{5}$

É inútil perguntar a razão pela qual a lembrança de Spix ficou desbotada à sombra de Martius. Spix pertencia a uma família provinciana de classe média baixa. Era solteiro e não teve oportunidade de treinar estudantes, porque a Universidade de Munique ainda não existia - ela só foi criada após sua morte. ${ }^{6}$

Spix e Martius sobressaem entre os mais importantes estudiosos da América do Sul. Spix foi o primeiro zoólogo que trabalhou na região amazônica, e é responsável por parte fundamental e básica de nosso conhecimento atual sobre a fauna do continente, especialmente sobre animais vertebrados.

Antes da viagem ao Brasil, trabalhou para a Academia de Ciências por alguns anos. Nesse período, desenvolveu importantes trabalhos sobre anatomia morfológica, biologia evolutiva e história natural, que lhe deram fundamentos para os empreendimentos científicos futuros, justificando a expectativa com que foram acompanhados.

\footnotetext{
${ }^{5}$ O material etnográfico reunido por Spix encontra-se depositado no Staatliches Museum für Völkerkunde, em Munique. Já as coleções zoológicas estão sob a guarda do Zoologishe Staatssammlung München.

${ }^{6}$ No ano do falecimento de Spix (1826), a Universidade de Landshut foi transferida de Ingolstadt para a capital do reino da Baviera, Munique (Lisboa, 1997).
} 
DEPOIMENTO

Spix e Martius uniram-se apenas para a expedição científica ao Brasil, e o grande sucesso da mesma é mérito de ambos. Pode-se imaginar que Spix sentiu mais intensamente o peso da responsabilidade pela expedição. Era o mais velho, o mais experiente, já ocupava alta posição na Academia e era o chefe da expedição. Coube a ele prestar contas dela e redigir o relatório para o rei.

Spix conheceu Martius em 1812, quando este ainda era um jovem estudante, na cidade de Erlangen. Depois que Martius se doutorou em medicina, Spix recomendou-o para o Jardim Botânico da Academia de Ciências de Munique, que o contratou como pesquisador.

Ambos são comparáveis no que se refere à extraordinária capacidade científica e à personalidade forte. Spix doutorou-se aos 19 anos e Martius, aos vinte. Com o mesmo entusiasmo, conscientes da missão que receberam do rei, eles viajaram pelo Brasil, mantendo uma relação de amizade e respeito mútuos, não obstante possuíssem características físicas e temperamentos diferentes (Lisboa, 1997).

Martius aceitou sozinho o reconhecimento mundial pelo relatório da expediçao, que foi publicado com o título Viagem pelo Brasil, 1817-1820, obra da qual faz parte ainda um atlas com um mapa do Brasil, o melhor que se havia produzido até aquela época. A terceira e última parte foi publicada em 1831, cinco anos após a morte de Spix. Martius viveu ainda mais 42 anos (faleceu em Munique em 1868, aos 74 anos. Durante esse tempo, pôde se dedicar a novas publicações feitas com base no material científico que ele e Spix reuniram no Brasil, como pode ser deduzido de seu diário, no qual consta que Spix participou da documentação das línguas indígenas, da elaboração dos desenhos dos rostos de índios e da coleção de outros materiais etnológicos. ${ }^{7}$

Spix retornou da viagem em condições precárias de saúde. Apesar de se sentir muito fraco, continuou a trabalhar arduamente. Tinha-se a impressão de que ele julgava ter pouco tempo de vida e, portanto, pouco tempo para viabilizar suas publicações. Por outro lado, parecia sentir o desejo de se preparar logo para retornar à região tropical e continuar suas pesquisas, ao contrário de Martius, que nunca mais teve vontade de viajar para os trópicos. O fato é que, seis anos mais tarde, Spix havia completado as descrições de cerca de quinhentas espécies de moluscos e vertebrados colecionados. Publicou primeiramente o trabalho sobre macacos e morcegos em um volume fabuloso (Spix,

\footnotetext{
${ }^{7}$ A documentação de Martius encontra-se depositada na Biblioteca Estadual de Munique. Sua produção intelectual abrange, entre outros, trabalhos em etnografia, lingüística, medicina indígena, cartografia e estudos botânicos. Entre seus trabalhos mais importantes, estão suas obras botânicas, como Nova Genera et Species Plantarum Brasiliensium, publicada em três volumes entre 1823 e 1831; Historia Naturalis Palmarum; e o ambicioso projeto da publicação da Flora Brasiliensis, em que colaboraram 66 botânicos de vários países, num total de quarenta volumes, com a descrição de 22.767 espécies de plantas. O último volume da Flora foi publicado em 1906
} 
DEPOIMENTO

1823). Em 1824, conseguiu publicar a descrição de tartarugas e de sapos.

Publicou também o primeiro volume sobre aves, com a ajuda do assistente J.G. Wagler, e o volume sobre cobras. Em 1825, vieram a lume as novas espécies de lagartos e o segundo volume sobre aves.

Logo depois da morte de Spix, foram publicados, sob a supervisão de Martius, o trabalho sobre moluscos, com o apoio de J.A. Wagner, que havia colaborado na coleta do material, e o trabalho sobre peixes, com o apoio de um jovem que então se achava em Munique, Luis Agassiz. A descrição dos insetos foi deixada a cargo do entomologista M. Perty, e foi publicada entre 1830 e 1834.

Moluscos e vertebrados foram bem preparados e conservados, e estão em grande parte disponíveis na Zoologischen Staatssammlung München.

Uma relação precisa dos objetos que ainda existem da coleção formada por Spix acha-se em um suplemento da Spixiana. Ali se encontra também uma relação do que foi conseguido por meio de permuta com os museus de Leiden, na Holanda, e Neuchâtel, na Suíça. A coleçao de peixes depositada em Munique foi destruída por ocasião do bombardeio da cidade em 1944, durante a Segunda Guerra Mundial, restando apenas a parte que fora levada para a Suíça por Agassiz. Além disso, um material entomológico não muito rico está sob a guarda da Zoologischen Staatssammlung München.

Como é sabido, os estrangeiros foram proibidos de viajar para o Brasil até a abertura dos portos em 1808, pelo príncipe d. João VI. Nem mesmo Humboldt conseguiu atravessar da Venezuela para o Brasil através do rio Negro. Só após a chegada da família real ao Brasil, o rigoroso estatuto colonial foi modificado.

Quando Spix e Martius chegaram ao Brasil, "quase todos os países da Europa estavam ali representados por intermédio de cientistas, colecionadores e também empalhadores", fato que relataram em uma primeira carta ao rei da Baviera. Juntamente com o príncipe WiedNeuwied e Johann Natterer, pertenceram ao primeiro grupo de pesquisadores de língua alemã autorizados a viajar e coletar espécimes. ${ }^{8}$ O pouco conhecimento que os europeus tinham sobre a fauna e a flora brasileiras baseava-se, ainda, em informações sobre a região Nordeste, de duzentos anos atrás, contidas em publicações da época ou em decorrência da ocupação holandesa chefiada pelo duque alemão

\footnotetext{
8 Johann Natterer (1787-1843), naturalista austríaco, chegou ao Brasil em 1817 com a comitiva que acompanhava a arquiduquesa Leopoldina. Passou 35 anos no país, coletando material zoológico, botânico e etnográfico para o governo austríaco. O material coletado por Natterer no Brasil encontra-se atualmente depositado no Museu de Viena. Maximiliano von Wied-Neuwied (1782-1867) chegou ao Brasil, com o pseudônimo de Max von Braunsberg, em 1815. Durante dois anos pesquisou a suas expensas o litoral do Rio de Janeiro, Espírito Santo e o sul da Bahia, alcançando Salvador. Reuniu, entre outros objetos etnológicos, vocabulários de tribos indígenas, plantas e animais. Seu livro de viagens foi publicado em 1820-21.
} 
DEPOIMENTO

Maurício de Nassau, e que mais tarde seriam utilizadas para a elaboração da obra de Lineu, Sistema de plantas e animais.

Até hoje, são utilizados para delimitação e estudo de espécies os tipos descritos por Spix, depositados na Zoologischen Staatssammlung München e nas coleções de Leiden e Neuchâtel. A coleção de macacos de Spix, por exemplo, foi utilizada por Hershkovitz (1977) em sua revisão taxionômica de espécies de macacos da América do Sul. É preciso ressaltar que ainda estamos longe de poder afirmar que conhecemos a fauna sul-americana, sobretudo os insetos e outros invertebrados. Sabe-se que até há pouco tempo existiam espécies ainda não descritas de macacos ocultas no que restou da Mata Atlântica.

Assim, o trabalho de Spix ainda possui grande importância. É o caso, por exemplo, dos volumes sobre anfíbios e répteis, escritos em colaboração com Wagler, e que foram publicados no Brasil por ocasião das comemorações dos duzentos anos de nascimento de Spix. Os dois volumes já tiveram várias edições. O prof. Paulo Vanzolini (1981, p. 26), então diretor do Museu de Zoologia do Estado de São Paulo, atual Museu de Zoologia da Universidade do Estado de São Paulo, responsável pela edição desses volumes, encerra a introdução com o seguinte comentário: "O trabalho herpetológico de Spix continua sendo fundamental para o estudo sistemático e ainda levará muito tempo até que se torne apenas uma curiosidade dentro de um armário."

Não é demérito para Spix saber-se que Maximiliano, príncipe de Wied-Neuwied, coletou mais animais vertebrados durante os dois anos de permanência no país (1811-13). O mesmo fez Natterer, do Museu de Ciências Naturais de Viena. Wied-Neuwied contou com o apoio de dois auxiliares alemães com experiência em coleta e preparação de animais. Natterer permaneceu 18 anos no Brasil. Spix e Martius registraram a desvantagem em que se achavam no primeiro relatório ao rei: "Diante de tanta riqueza de formas, não temos mãos e olhos suficientes para realizar nosso trabalho. Cada um de nós teria que ser pintor, empalhador, caçador e herborista para poder representar e reunir toda esta riqueza."

O príncipe restringiu-se, em sua viagem, ao estudo da fauna dos vertebrados de uma região de fácil acesso, na serra do Mar, entre Bahia e Rio de Janeiro; nao precisou fazer um catálogo como aquele encomendado a Spix e Martius pela exigente Academia de Ciências de Munique. Além de estudar a fauna e a flora, eles teriam que reunir dados geográficos, geológicos e climatológicos e, ainda, informações sobre os habitantes da região e as riquezas do solo, a estrutura política e econômica, informações que interessavam ao rei da Baviera.

Wied-Neuwied publicou suas ilustrações e contribuições para a história natural do Brasil no mesmo período que Spix e Martius (182232), e sua obra é também considerada o que de melhor se escreveu sobre o Brasil na época. Natterer, como já mencionamos, passou 18 anos coletando animais, muitas vezes, assim como Spix e Martius, em 
regiões onde nenhum europeu tinha ainda pesquisado. Após seu regresso, por motivo de saúde, não teve mais condições de tirar proveito do imenso produto de seu trabalho. Seu diário queimou-se, lamentavelmente, no Museu de Viena, em 1848, cinco anos depois de sua morte (1843).

A Viagem pelo Brasil de Spix e Martius revelou ao público os resultados pormenorizados de uma extraordinária expedição científica. Ninguém, naquela época, poderia deixar de almejar resultados comparáveis aos obtidos por Humboldt na América Central e no Norte do continente sul-americano. Nenhum outro empreendimento científico serviria para essa comparação.

A capacidade científica de Spix só pode ser avaliada tendo-se em mente as atividades que resultaram em Viagem pelo Brasil. Os volumosos dados reunidos para a execução do mapa e sobre geografia, geologia, população, economia e história do Brasil foram, em sua maioria, compilados a partir do diário e dos desenhos de Spix. Pelo menos na preparação do segundo volume, a responsabilidade de escrever esteve nas mãos de Martius.

O grau de identificação de Spix com o Brasil, a segurança com relação aos conhecimentos sobre a sua história são facilmente perceptíveis no discurso proferido em dezembro de 1821, um ano depois de seu retorno, na Academia Real de Ciências da Baviera, sob o título 'O Brasil e seu desenvolvimento, desde a descoberta até nossos dias' (Spix, 1821).

O discurso é uma preciosidade literária. Está repleto de dados e de afirmações que não perderam o valor. Denunciava, por exemplo, a forma como o príncipe regente de Portugal procurara implantar uma lei em 1808: "Deve cessar a destruição da floresta decorrente do excessivo desmatamento para a construção de casas, a instalação de fábricas de açúcar e a escavação de minas de ouro.”

É difícil imaginar, hoje, o que Spix sentiu no primeiro contato com o Rio de Janeiro. No mencionado discurso, ele mostra-se ainda possuído pelo entusiasmo com a região tropical brasileira, entusiasmo partilhado por Martius, que lhe deu forças para executar a missão delegada pelo rei e vencer todas as dificuldades que se apresentavam durante aqueles quatro anos de estada no Brasil. Cito um trecho retirado do discurso (Spix, 1821, pp. 31-2): "A lembrança da Europa é, nesse meio tempo, cada vez mais longínqua. Deixando para trás as ruas da cidade, temos diante de nós a livre, majestosa e bela natureza: palmeiras e bananeiras que agitam suas folhagens, montanhas de melastomáceas (quaresmeiras), micáceas, malváceas, crotonáceas, encostas cobertas de aloés (babosa/ piteira) e cactos, planícies repletas de arbustos com ramos de mimosas, acácias, lantanias (cambará), buganvilias, asclepidáceas (oficial-de-sala), goiabeiras e cajueiros, grumixameiras e outras agradáveis mirtáceas, cuja beleza é realçada pelo sussurro de coloridos beija-flores e pelas formas e magníficas cores das borboletas, que voam ao nosso redor. 
DEPOIMENTO

Em segundo plano, vêem-se as montanhas, que se elevam com a beleza silvestre e eternamente verde da fria floresta de árvores de troncos colossais, encimados por uma coroa de galhos e folhas que, na estação do amor, são recobertos de flores como as de cesalpináceas, lecitidáceas, Geoffräen cedrelas, lauráceas, figueiras e outras. Do alto destes galhos pendem, como serpentinas, ramos de trepadeiras com flores brancas, vermelhas e azuis, de formas esplendorosas, como as de maracujá, begônias, paulínias, clusiáceas. Junto com espécies de aráceas e a aromática baunilha, que como esplêndidas guirlandas enfeitam os troncos das árvores, as helicônias, as briófitas arbóreas e majestosas palmeiras, que cobrem como capim o solo, o montão de diferentes espécies de aves, borboletas e outros insetos que competem em esplendor de cores e brilho com o sol, e com os sons que emitem, encantam os ouvidos humanos. Tudo prendeu nosso olhar e nos permitiu sentir a totalidade das diferenças de plantas e animais, que nos fizeram considerar de forma nova e exuberante, com sua natureza, a existência de um mundo mais belo e feliz que a Europa."

Nem a personalidade do dr. Johann Baptist Ritter von Spix nem o significado de sua atividade para a época foram, até o momento, satisfatoriamente explorados. Existem poucas referências às características pessoais de Spix. Uma consulta ao diário de Martius ou a determinados arquivos - da Academia ou dos Arquivos Reais da Baviera e do Estado da Baviera (Bayerische Akademie der Wissenschaften, Munique) - poderia fornecer subsídios que não encontramos nas poucas e resumidas biografias. O próprio Martius, ao escrever o necrológio, registrou escassas informações sobre a formação científica de Spix, e se limitou a mencionar fatos pouco representativos, de forma sóbria e comedida. Martius tomou conta de tudo o que Spix deixou. Do diário deste, que foi perdido, restaram apenas fragmentos, fato que até hoje permanece não esclarecido. Uma estudante, da qual fui orientador, apresentou este ano uma tese de doutoramento sobre a visão de mundo filosófica de Spix. É de se desejar que outros estudos venham tornar mais verdadeira a nossa imagem de Spix.

A mais representativa biografia dele, ainda assim superficial, foi publicada treze anos após sua morte, num pequeno jornal regional (Anônimo, 1839). Ao lado de muitas afirmações contraditórias, alude à sua situação financeira, declarando que teria ganho dinheiro com a venda de madeira brasileira, o que não é verdade. No entanto, essa biografia também faz menção a: "Um aspecto importante do caráter do ilustre falecido, ainda não conhecido. Ele mostrava-se pouco comunicativo e reservado, diante de muitos; na maioria das vezes, porém, no círculo dos poucos amigos, exibia muito bom humor, era alegre e animado."

Quando se lê o primeiro relatório de viagem escrito após a chegada ao Rio Janeiro, vê-se que os curiosos Spix e Martius não tiveram dificuldade em estabelecer importantes contatos nas 
localidades percorridas, tendo em vista o trabalho de pesquisa a desenvolver. Eles eram muito considerados pelo embaixador russo, Georg Heinrich von Langsdorff, e também pelo mineralogista e barão W. L. von Eschwege, o responsável pela exploração das riquezas do solo brasileiro. ${ }^{9}$ Com este último, Spix planejou a publicação de um periódico no Brasil. Encontraram também pessoas que se interessaram em participar da viagem pelo interior do país. O pintor Thomas Ender ${ }^{10}$, por exemplo, ligado ao grupo austríaco, logo fez amizade com Spix e Martius e os acompanhou a São Paulo. É evidente que Spix não tinha problemas para se relacionar com as pessoas. Ele e Martius gozavam de muita confiança nos círculos oficiais do Rio de Janeiro, e seu prestígio junto ao imperador valeulhes a abertura de uma exceção, quando já estavam na Bahia: foram autorizados a ingressar no distrito do diamante, no Pará, região ainda vedada aos estrangeiros.

Tem-se a impressão de que Spix dedicou toda sua vida ao estudo e à atividade científica. Era decidido e conseqüente em relação a seus ideais e convicções, e estava sempre pronto a defender sua opinião de forma corajosa, característica que está ligada à sólida formação que teve.

Sétimo de 11 filhos, Johann Baptist Spix nasceu em 9 de fevereiro de 1781 na pequena cidade de Höechstädt am der Aisch. Com 11 anos (1792), ingressou na Escola Episcopal de Bamberg. Era um menino de constituição física débil, sem recursos financeiros, porém dotado de inteligência excepcional. O pai, que faleceu cedo, foi nomeado para uma função similar à que Tiradentes exercia no Brasil: era barbeiro, dentista, farmacêutico e ainda cirurgião-médico. Foi também um respeitado conselheiro de sua cidade. A mãe de Spix era filha de um comerciante italiano. Dizem ter sido herdado dela o temperamento que Johann desenvolveu e que lhe causou problemas, mais de uma vez; o gosto pela pesquisa da natureza teria recebido do pai.

Em 1793, o jovem Spix transferiu-se para o Seminário Episcopal, em Bamberg, onde se destacou como o melhor aluno. Em 1800,

\footnotetext{
${ }^{9}$ Georg Heinrich von Langsdorff (1774-1852), alemão formado em medicina e ciências naturais em Göttingen. Após uma rápida passagem pelo Brasil em uma viagem de circunavegação em 1803, retornou em 1813 como cônsul-geral da Rússia, permanecendo no país por sete anos. Durante sua estada, ajudou e orientou os naturalistas estrangeiros que aqui chegavam. Promoveu expedição científica sob os auspícios da coroa russa, percorrendo o interior do país entre 1824 e 1828. Wilhelm Ludwig von Eschwege (1777-1855) alemão natural de Aue, perto de Eschwege, no Hesse-Nassau, contratado pela coroa portuguesa para desenvolver pesquisas mineralógicas em Portugal, foi transferido para o Brasil em 1811, com a incumbência de se ocupar da exploração do solo e aproveitamento do carvão e minério de ferro.

10 Thomas Ender (1793-1875), chegou ao Brasil em novembro de 1817, acompanhando a comitiva da arquiduquesa austríaca Leopoldina de Habsburgo. Durante sua estada de oito meses, produziu oitocentos desenhos, aquarelas e guaches da paisagem e cotidiano da época. Sua obra brasileira encontra-se atualmente na biblioteca da Academia de Viena.
} 
DEPOIMENTO

com 19 anos, doutorou-se em filosofia. Incentivado pela igreja, ingressou em 1801 no Seminário Episcopal para Preparação de Sacerdotes, em Würzburg, mas três anos depois abandonou o estudo da teologia para se dedicar à medicina e às ciências naturais. Nesse período, Spix foi um aluno entusiasmado de Schelling, então um filósofo da natureza muito famoso. Spix garantia sua subsistência com o que auferia como professor particular. Em 1807, doutorou-se em medicina e começou a exercer a profissão em Bamberg. Schelling influiu consideravelmente na formação de Spix. O filósofo ficou impressionado com a brilhante inteligência do estudante, a consistência de seus estudos anteriores em filosofia, seu grande conhecimento das ciências naturais e a busca incansável e ambiciosa pelo conhecimento em geral. De outro lado, o caráter de Spix era influenciado pelas novas idéias românticas desenvolvidas pelos filósofos naturais, como Emmanuel Kant e Friedrich Wilhelm Josef von Schelling. O pesquisador de ciências naturais defrontava-se, então, na época, com o seguinte questionamento: como seria possível que os conhecimentos isolados sobre a natureza orgânica e inorgânica fossem reunidos numa só teoria do conhecimento, em que as relações entre matéria e espírito formassem uma unidade natural. Tal questionamento encontra sua formulação atual, por exemplo, no trabalho do grande biólogo Edward O. Wilson, que ambiciona "a unidade do conhecimento".

Schelling foi transferido de Würzburg para Munique, em 1806, para ali organizar a Academia de Ciências da Baviera. É provável que tenha sido ele o responsável pela contratação do jovem médico Spix pelo Ministério do Estado da Baviera para instalar o Gabinete de Zoologia da Academia. Antes de ser aceito por ela na academia, Spix foi submetido a uma prova de anatomia comparada. O rei Maximiliano José I e seu ministro Montgelas ficaram convencidos de que o candidato era capaz, tanto que financiaram sua permanência por dois anos em Paris - na época, a metrópole da zoologia — para que se preparasse bem para a atividade que iria exercer.

Para Spix, foi a realização de um sonho poder ouvir Georges Cuvier, o homem que deu novo sentido à zoologia, com sua taxionomia, anatomia comparada e suas pesquisas paleontológicas; poder conviver com Blainville, discutir com Jean Baptiste de Lamarck e Auguste de Saint-Hilaire sistemática, biogeografia e os problemas relativos à evolução que então começavam a surgir. O espírito que norteava a pesquisa em ciências naturais era racional, indutivo e sistemático, e não filosófico, como aquele que presidira à formação de Spix. Ele precisou demonstrar sua capacidade, aplicação e entusiasmo ao conquistar o privilégio de utilizar a rica biblioteca e a maior coleção do mundo no recém-criado Museu Nacional de História Natural, no Jardim Botânico de Paris. Ele empreendeu longa excursão da costa britânica ao Sul da França. Viajou da Suíça até a Itália, subiu o Vesúvio, teve grande satisfação em conhecer o que restou do mundo antigo, em ler 
Dante, tanto quanto em conhecer a fauna marinha e a flora do Mediterrâneo. E, durante todo esse tempo, coletou material para a Academia de Ciências de Munique.

Logo no primeiro ano, ainda na França, examinou e descreveu os ovários e o sistema nervoso do ouriço, e acumulou material para diferentes trabalhos que iria publicar mais tarde. Essas atividades consolidaram seu interesse pela zoologia. Sua estada em Paris foi encerrada com seu primeiro grande trabalho científico, $A$ bistória e a crítica dos sistemas de zoologia, em seu desenvolvimento, desde Aristóteles até os nossos dias. (1811).

Embora tivesse muitas ocupações durante a construção da Zoologischen Staatssammlung München, nas precárias instalações da Academia, especialmente em seu início, continuou a se esforçar para não interromper o trabalho científico.

Em 1814, publicou um precioso e pormenorizado estudo sobre a anatomia da sanguessuga, muito usada na época em medicina (Spix, 1814a). A experiência adquirida na escola parisiense na preparação desse material permitiu-lhe esclarecer, pela primeira vez, os vasos sanguíneos e o sistema nervoso desse grupo de animais. No mesmo ano, apresentou uma contribuição à taxionomia geral dos macacos conhecidos na época (Spix, 1814b). Pouco tempo depois, publicou, em latim, o grande e sofisticado trabalho Cephalogenesis (1815), no qual procurava justificar a necessidade da compreensão filosófica natural em um estudo osteológico comparativo sobre os crânios de mais de cem vertebrados, com o objetivo de decifrar a evolução da cabeça até as vértebras da coluna vertebral. Goethe, uma autoridade em anatomia comparada e morfologia, que já havia elogiado a dissertação de Spix sobre os sistemas da natureza, qualificou Cephalogenesis como um trabalho de grande envergadura. Nunca um crânio de animal ou ser humano tinha sido estudado e descrito tão detalhadamente.

A segurança de Spix nos vários domínios da história natural e a experiência adquirida nas viagens anteriores permitiram-lhe planejar e coordenar com firmeza a viagem de estudos ao Brasil, que empreendeu junto com o jovem Martius, na época com 22 anos. Teve de se submeter a uma curta preparação antes da viagem.

Quando regressaram à Baviera, Spix e Martius receberam o título de cavaleiro e uma renda vitalícia. Existem nos arquivos da Academia de Ciências Naturais da Baviera muitas informações sobre as dificuldades que o jovem Spix enfrentou no início da carreira científica. Também lhe foi difícil organizar uma coleção zoológica segundo uma visão mais atualizada para a época.

Spix foi um inovador audacioso. Quando se achava ainda em experiência, o rei o nomeou curador da Coleção Zoológica e Zootômica, apesar dos protestos dos acadêmicos mais velhos, condição que lhe conferiu status nesta instituição. Ele nunca interrompeu o seu amadurecimento científico, dedicando-se ao estudo das grandes relações 
existentes na natureza, da evolução dos organismos e sua interação com o ambiente. Durante simpósio sobre Spix, em 1981, ressaltou-se que ele foi capaz de unir filosofia e pesquisa concreta, e de defender este equilíbrio, de forma conseqüente, como professor na universidade.

Como dissemos, a apresentação de Schelling foi muito importante para que Spix ingressasse na Academia, porém ele mereceu o cargo a que se dedicou com tanto empenho. De forma criteriosa, organizou a zoologia em Munique. Seu trabalho recebeu, naquela época, e recebe ainda hoje, elogios e reconhecimento. Seu nome permanecerá unido à história das pesquisas sobre a fauna sul-americana, em especial a do Brasil.

\section{Ficha técnica:}

Texto resultante de palestra proferida na Fundação Oswaldo Cruz em dezembro de 1998

Tradução da palestra: Maria da Conceição Messias

Edição de texto: Jaime Benchimol e Magali Romero Sá

Documentos e imagens em anexo reunidos e preparados por Ludwig Tiefenbacher, pesquisador do Zoologischen Staatssammlung München

Agradecimento dos editores

Ao Dr. Franz Schuhwerk, curador das fanerógamas II do Botanische Staatssammlung, que gentilmente providenciou as fotos do material pertencente ao herbário de Martius; ao staff do Zoologische Staatssmmlung, pelas horas dedicadas à separação e fotografia do material zoológico coletado por Spix, e, em especial, ao Dr. Ludwig Tiefenbacher, curador chefe da Zoologia dos Invertebrados do Zoologische Staatssammlung, Munique. Dr. Tiefenbacher gentilmente providenciou a fotocópia da correspondência relativa à viagem de Spix e Martius ao Brasil, depositada no Bayerisches Hauptstaatsarchiv, em Munique, e transcreveu todos os textos para a escrita moderna para que pudessem ser traduzidos. Além disso, encarregou-se de reunir toda a documentação e iconografia selecionadas em Munique e enviá-las ao Brasil. À ele nossos sinceros agradecimentos. 


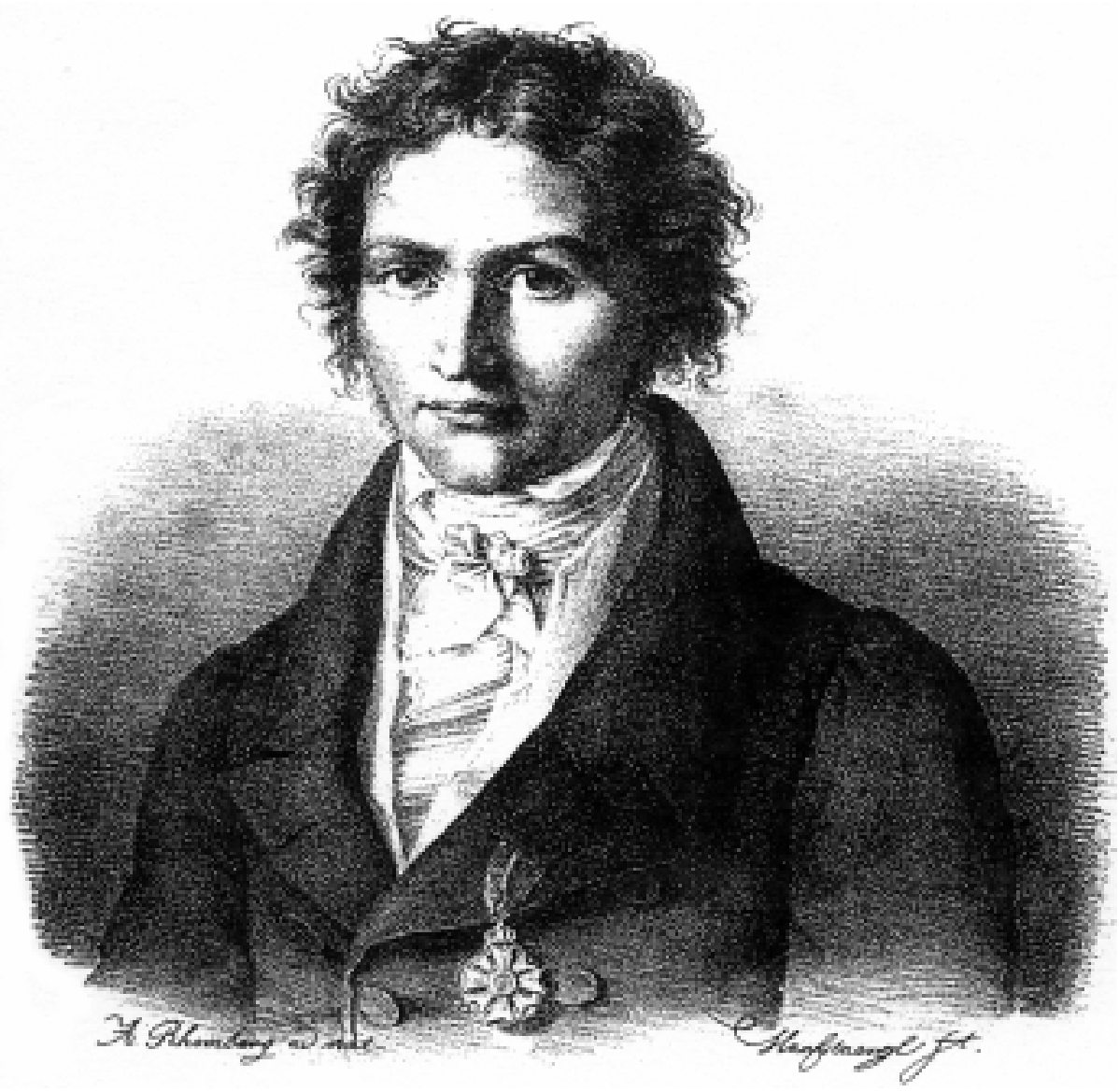

DEPOIMENTO

J. B. Ritter von Spix com a ordem (Civilverdienstorden der Bayerischen Krone). Desenho de Rhomberg, litografia de Hanfstaengl, Munique.

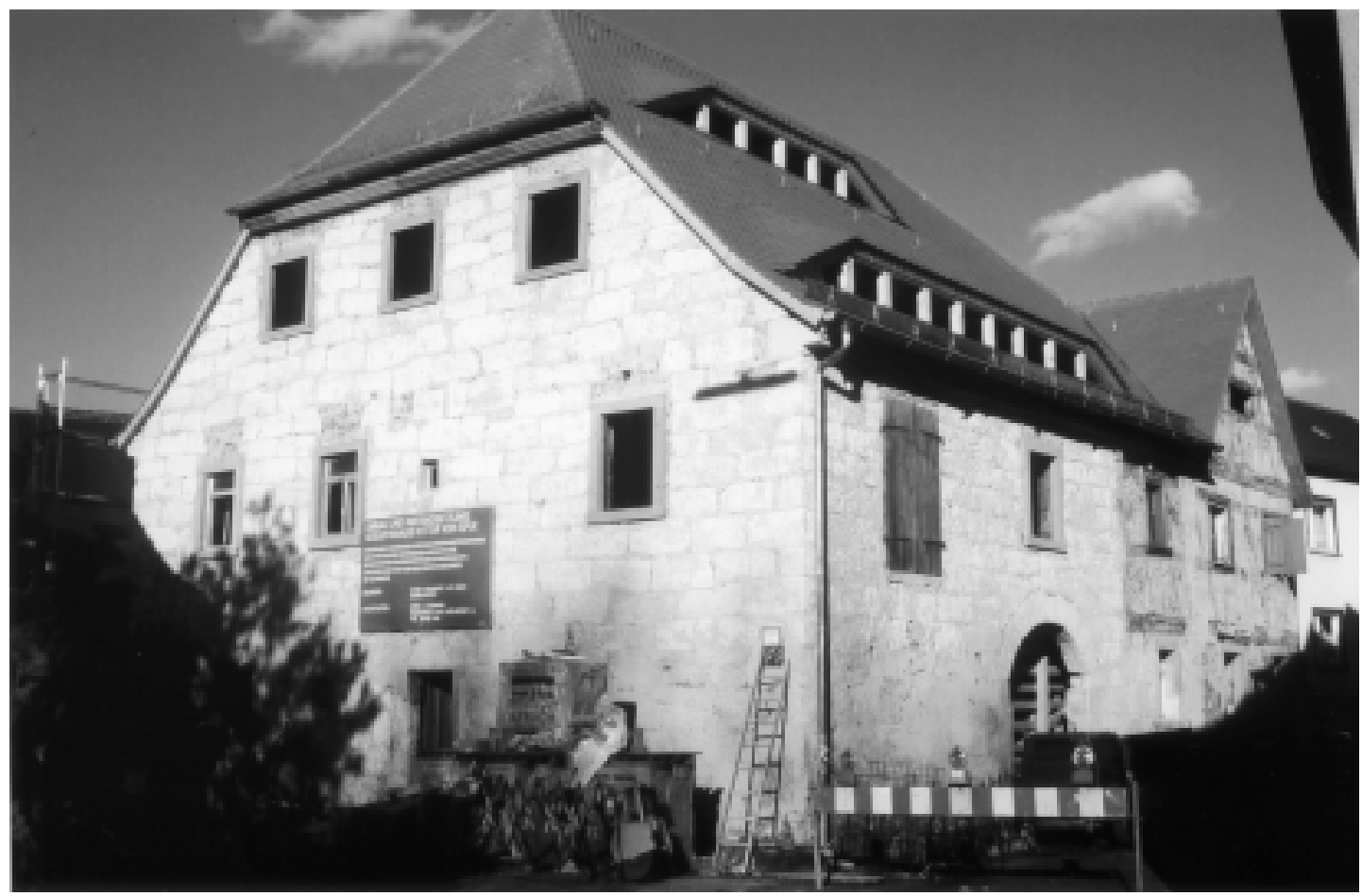

Casa onde nasceu Spix em Höchstadt an der Aisch. Archive of Stadtverwaltung Höchstadt an der Aisch. 
DEPOIMENTO

Reino da Baviera

Ministério dos Assuntos Estrangeiros

Por ordem de Sua Majestade o Rei

O Ministro de Estado Conde von Montgelas

Ao

Encarregado de Negócios Imperial Barão

von Steinlein em Viena.

Após a Majestade o Rei da Áustria permitir a dois sábios bávaros viajar no séquito do próximo Embaixador que parte para o Brasil, Conde v. Eltz, concedendo aos mesmos livre sustento, recebe agora o Encarregado dos Negócios Barão v. Stainlein a incumbência de expressar ao Príncipe v. Metternich, em nome de Sua Majestade, o mais vivo agradecimento por esta nova prova de amizade de sua corte, e de anunciar pelo mensageiro que retorna a época em que partirá a partida da comitiva do Embaixador e alguns detalhes sobre a própria viagem, para que o Acadêmico e Conservador da coleção zoológico-zootômica, Doutor Spix, e o Adjunto da Academia e Botânico Dr. Martius possam chegar antes do referido dia a Viena.

Munique, 19 de janeiro de 1817

Pelo Ministro

o Secretário Geral

v. Baumüller

Sobre a viagem de dois sábio bávaros

Com o Embaixador Imperial austríaco

ao Brasil 
Carta de Graf von Montgelas para o embaixador bávaro Freiherr von Stainlein (Viena). Correspondência relativa à viagem de Spix e Martius ao Brasil depositada no Arquivo Bayerisches Hauptstaatsarchiv

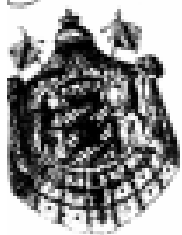

anow artigen ofygelegentisciten

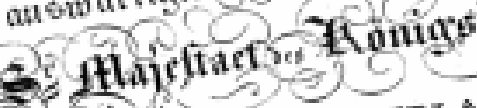
-

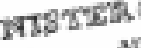

5yfolly

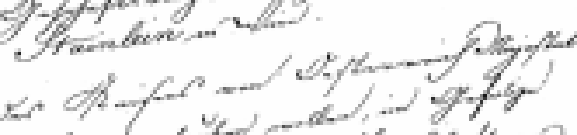

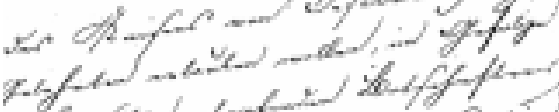

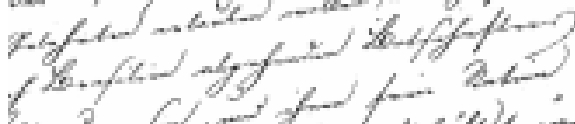

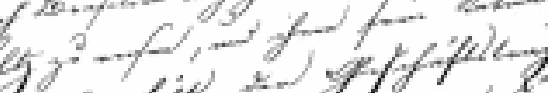

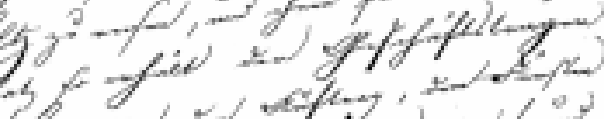

Chincin

若

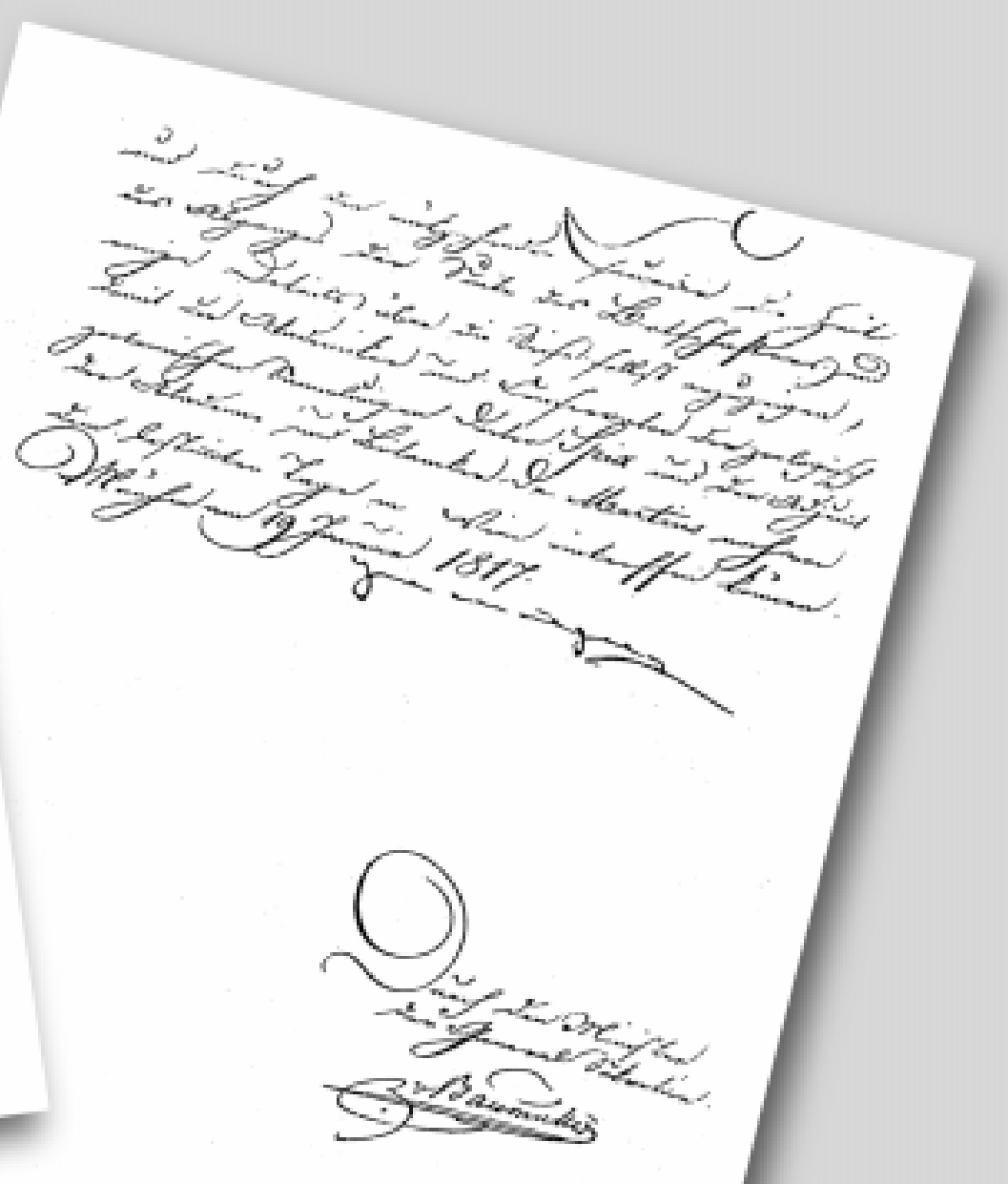


DEPOIMENTO

№ 971

\section{Vossa Excelência}

Teve a bondade de nos enviar o outro decreto supremo com relação à viagem com o Sr. Conde von Wrbna. Apressamo-nos em transmitir aqui os primeiros relatos sobre nossa chegada, já anunciada através de Londres, e rogamos a Vossa Excelência que deduza dos relatos aqui remetidos as nossas condições atuais, e que repasse logo em seguida, por obséquio, os mesmos lacrados a lugar e repartição. Com a fragata Áustria esperamos enviar, tão logo ela parta, o primeiro frete; este deve levar também o vinho para nós comprado na Madeira pelo sr. barão von Neven, 250 garrafas em parte para o nosso Rei e para V. Excelência. Neste país magnífico só falta o homem europeu, sobretudo o alemão, para nos alegrar com sua companhia. Até o momento tivemos de restringir a circulação de nossos pensamentos a nós mesmos. Aliás, mesmo entre os estrangeiros toda indústria é nacional e destinada a bastante estoque. O conde v. Fläming é muito obsequioso conosco. Com que freqüência erramos neste paraíso despovoado pensando no Senhor e no iniciador e patrono desta viagem, desejando estar com o Senhor! O final desta viagem mostrará que, com esta viagem, Vossa Excelência não apoiou um empreendimento pequeno. Entregamo-nos à vossa mais distante benevolência e subscrevemo-nos com a mais alta atenção

Rio Janeiro ${ }^{1}, 07$ de setembro de 1817

A Vossa Excelência

O Conde v. Fläming e Sr. Barão v. Neven

incumbiram-nos de saudar V. Excia.

Com obediência e o mais atenciosamente Dr. Spix Membro e Conservador Dr. Martius Adjunto

${ }^{1}$ Conforme o original (N. do. Trad.). 
Carta de Spix e Martius do Rio de Janeiro para Freiherr von Stainlein (Viena).

Correspondência relativa à viagem de Spix e Martius ao Brasil depositada no Arquivo Bayerisches Hauptstaatsarchiv em Munique

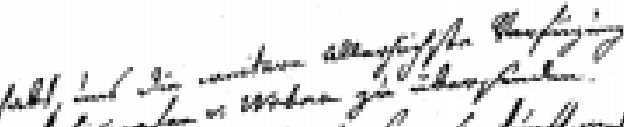

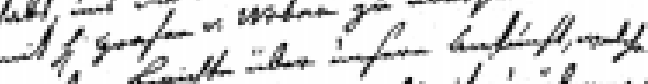

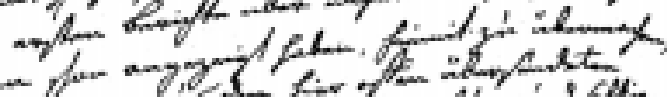

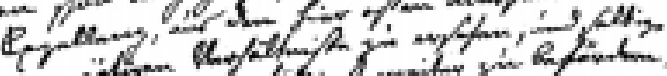

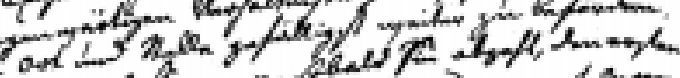

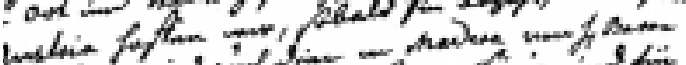
mentor

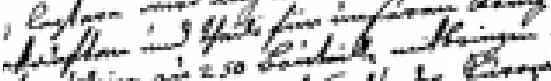

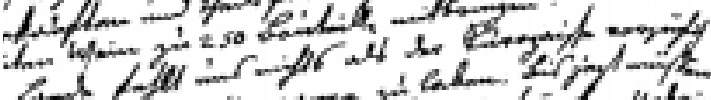

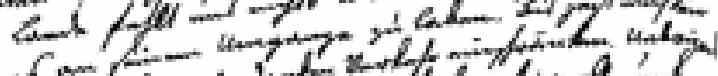

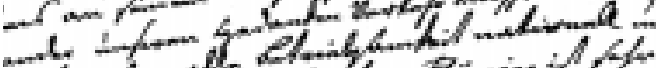

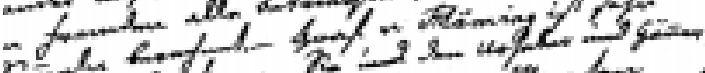

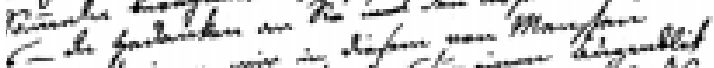
mot

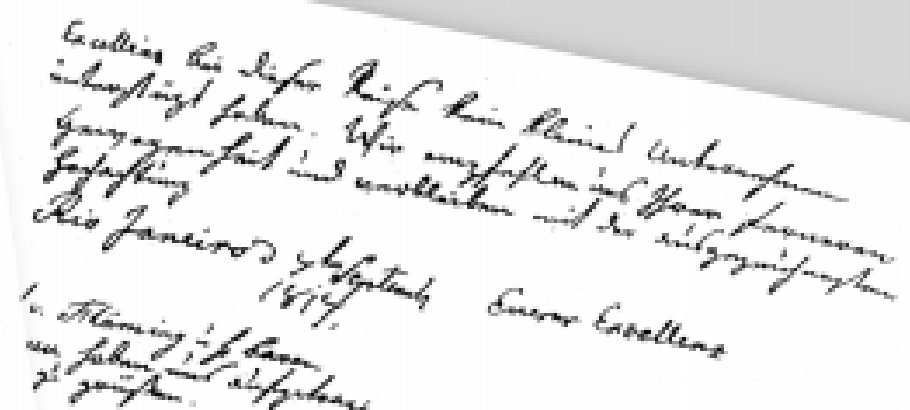

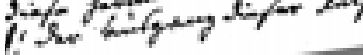


DEPOIMENTO

Bahia, 14 de fevereiro de 1819

Ao ilustríssimo Senhor Barão von Stainlein, Ministro Imperial bávaro plenipotenciário na Corte Imperial austríaca em Viena

Ilustríssimo, mui idolatrado

Senhor Barão!

Vossa Excelência receberá nossa última carta de Villa Rica, de final de abril de 1818, e verá que prosseguimos a viagem de São Paulo a Sorocaba, ao Porto de São Félix, onde pelo Tietê se aporta em Mato Grosso, Itu, Jundiaí, daí para São João del Rei e a capitania de Minas Gerais, rica em ouro. Em Villa Rica, o centro de tão ricas minas, permanecemos dois meses, sem deixar de fazer diferentes incursões para o rio da Pomba, por exemplo, onde, em meio a florestas, tivemos a oportunidade de observar os índios coroados, puri e coropos em sua condição selvagem natural; para Caupon, onde são obtidos os topásios amarelos; subimos também as serras adjacentes e medimos a majestática montanha Itacolumy, em cujo sopé ergue-se a Villa Rica. Acreditando haver examinado todos os locais de lavagem de ouro dispersos aqui e ali, e ter reunido todas as coleções devidas, partimos por Sabará, Coaes, Villa do Príncipe para Tijuco. Nada almejamos mais ardentemente do que sermos admitidos no distrito dos diamantes, cujo ponto central é o Tijuco. Infelizmente, já tínhamos escutado em Villa Rica que o Rei, no Rio Janeiro, logo depois de nos ter concedido permissão para irmos lá, expediu contra-ordem pela qual o distrito dos diamantes e as grã-províncias do Pará, Rio Negro, Matto Grosso, Rio Grande do Sul permanecem vedadas a todos os estrangeiros indistintamente. Para nossa sorte, o intendente, liberal e muito simpático à ciência, conhecido como melhor aluno de Werner, sentiu alegria de poder falar alemão conosco e descumpriu aquela determinação, permitindo sem delongas o nosso ingresso. Examinamos todas as minas possíveis, subimos a montanha mais alta de nossa viagem, Itambé, próxima do Tijuco, e tivemos a sorte de medir barometricamente esta cadeia de montanhas, tão importante para se compreender a formação dos diamantes e considerada até agora inacessivel; pôde ser escalada com o maior perigo e esforço, na verdade também só com a ajuda do intendente, que mandou abrir um caminho através da floresta, ao pé da montanha. Com a permanência de um mês, acreditamos ter esgotado tudo, e deixamos os maravilhosos campos do Tijuco que, como os mais belos de toda a nossa viagem, pareceram escolhidos para guardarem as mais belas e luminosas pedras. Partimos para Minas Novas, na qual há florestas próximas ao litoral, faltam os diamantes e o ouro torna-se também mais 
Carta de Spix e Martius da Bahia para Freiherr von Stainlein (Viena). Correspondência relativa à viagem de Spix e Martius ao Brasil depositada no Arquivo Bayerisches Bahia XID. Fo. 4 .

torthworles. Taton von basi. bevall. mimistery am ishen llofe Hauptstaatsarchiv em Munique $z^{2}$ Wien.

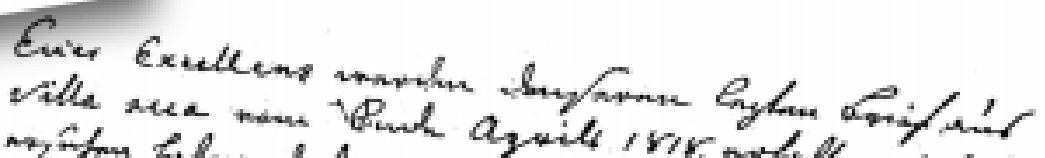

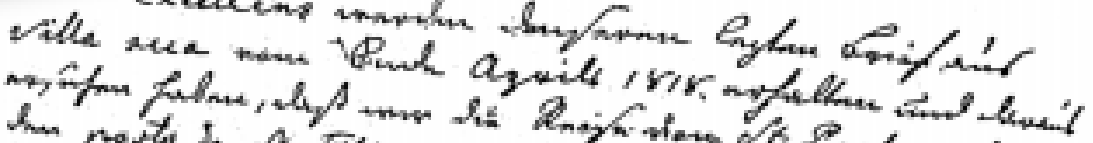

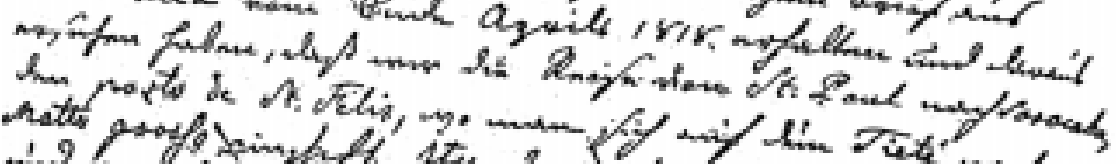

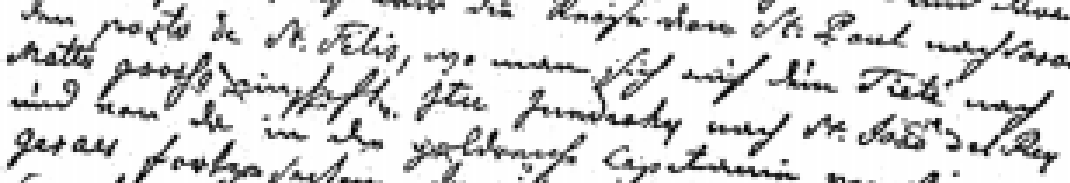

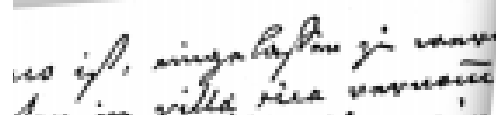

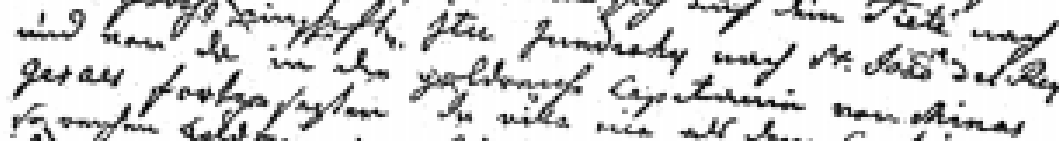

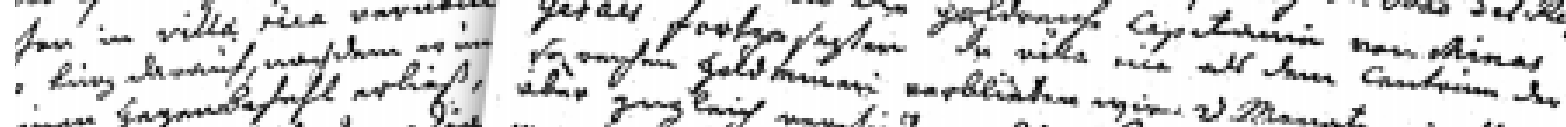

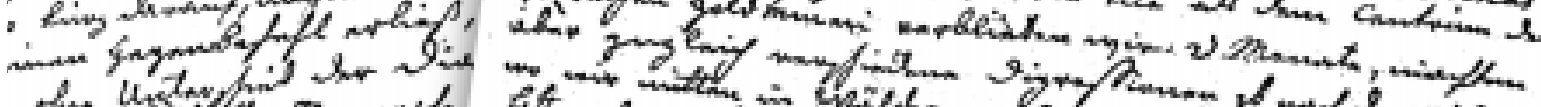

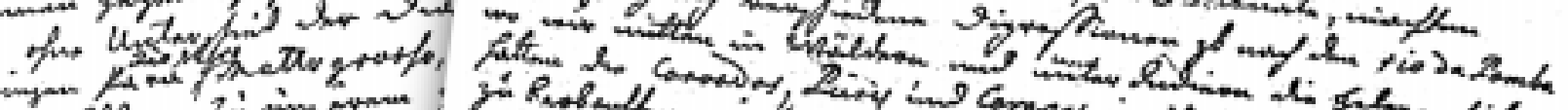

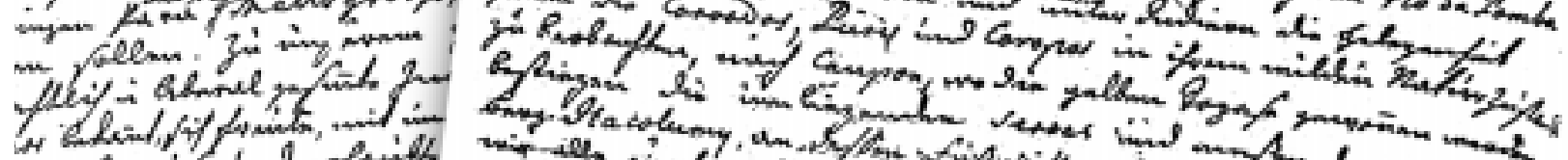
H ing fincting wenids

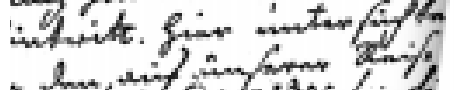

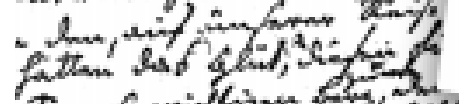

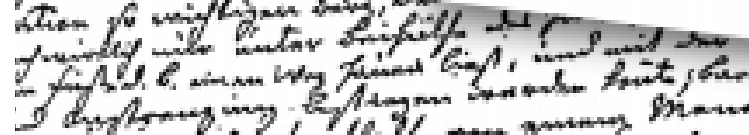

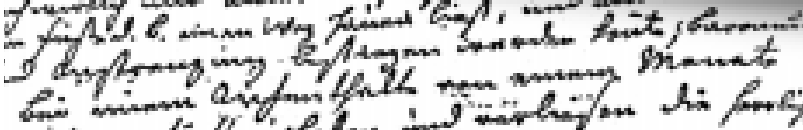

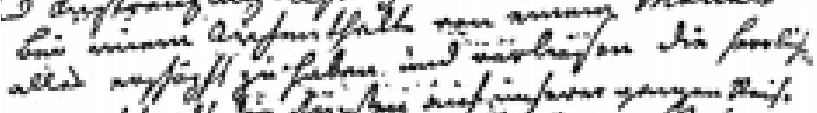

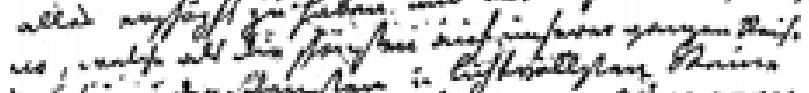

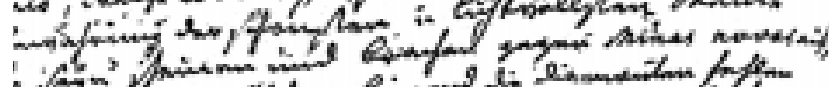

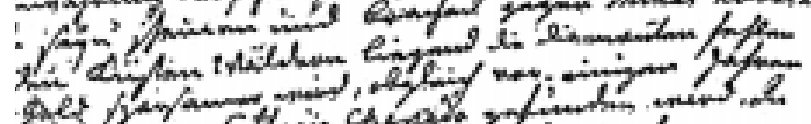

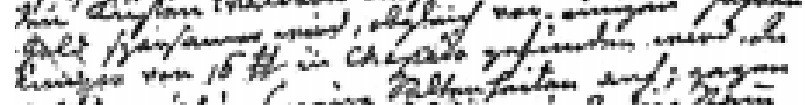

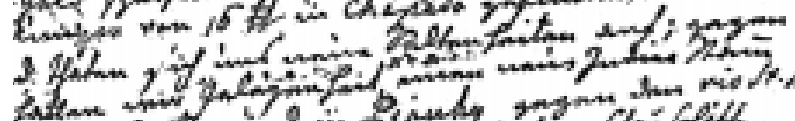

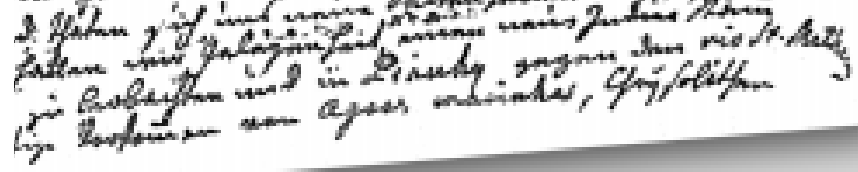


escasso, ainda que tenha sido encontrada há alguns anos, na chapada, uma pepita inteira com 16 (quilates). Neste lugar descortinaram-se para nós outras raridades; em direção ao Alto dos Bois tivemos a oportunidade de observar uma nova tribo de índios, os macuanhys, e no Piauhy, em direção ao rio São Mateus, pudemos examinar, na própria formação geológica, o surgimento freqüente de águas marinhas, crisólitos, topásios brancos e azuis, granadas, pingos d'agua, esmeraldas. Estas excursões secundárias foram por certo muito interessantes, mas extremamente fatigantes e desfavoráveis à saude. Do Piauhy, para aonde havíamos viajado em quatro dias, em cavalos alugados (10 léguas por dia), apressamonos em ir ao encontro de nossa tropa, que estava em São Domingo, próxima de Arassuahy, zona rica em ouro, e do principal rio para diamantes do Jequitinhonha. Assim como os campos de Minas Gerais, repletos de ouro, compensam a pobreza da produtividade com a abundância do minério e a bela paisagem, aqui também o solo pobre em ouro avulta em fecundidade: ao redor de São Domingo todas as colinas estavam densamente cobertas por arbustos de algodão. Em Tocajos, onde o Arassuahy conflui com o Jequitinhonha, em Belmonte flui para o mar e é utilizado atualmente pelo governo daqui como via para Minas, tivemos a horrível visão dos botocudos comedores de gente: totalmente nus, arco e flecha nos ombros, lascas redondas pendentes nas orelhas e da mesma forma no lábio inferior, sobre o qual estão habituados a colocar comidas como sobre uma mesa, as partes masculinas numa cápsula de junco do pântano, assim passou diante de nós uma horda destes animais já mais mansos; uma mulher, ferida por seu marido ciumento com flechas em todas as partes do corpo, esforçava-se por seguir o cortejo. Em Tocajos passamos pelo rápido Jequitinhonha, atravessamos a serra de diamantes de Santo Antônio e avançamos sertão adentro, habitado mais por animais selvagens do que por homens. Paulatinamente nos aproximamos do fim da primeira catástrofe, isto é, pelo São Francisco, que corre na divisa entre Goiás e Minas, entre Pernambuco e Bahia, desaguando no mar em Penedo. Em importância, é o terceiro rio do Brasil, tem apenas $1 / 2$ stunde ${ }^{2}$ de largura, e seria um dos rios mais belos e fecundos se o seu transbordamento anual em Três Lagoas não tornasse suas margens quase inabitáveis, e as estações - as primaveras frias ${ }^{3}$ - e os tipos daí decorrentes tão mal afamados. As lagoas são muito apreciadas pelos animais selvagens; estão coalhadas de pássaros

\footnotetext{
${ }^{2}$ Nota do tradudor, medida equivalente 4 a $5 \mathrm{~km}$

${ }^{3}$ No original kalt. F. Desconheço terminologia. (N. do Trad.). Traduziria por primavera fria caso seja kalter Frühling.
} 


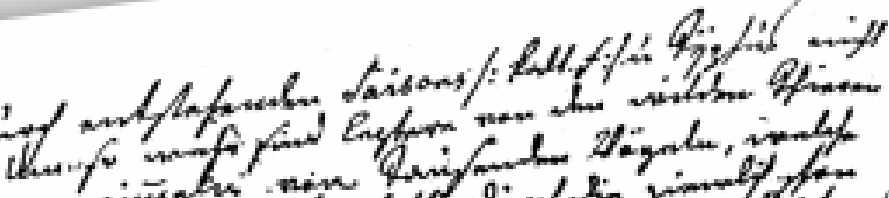

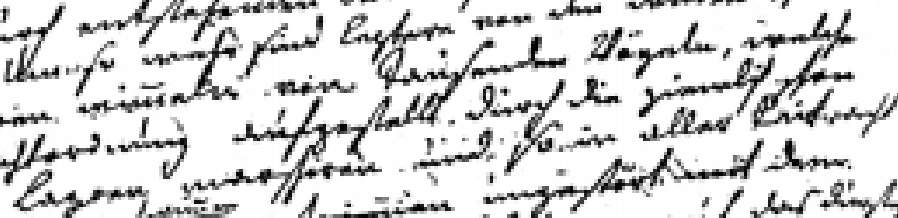

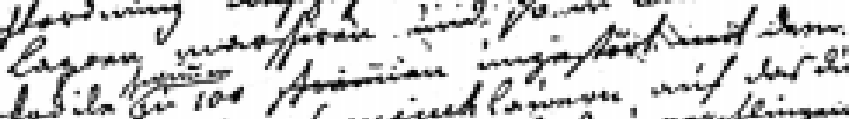

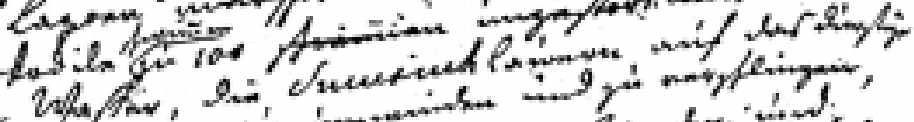

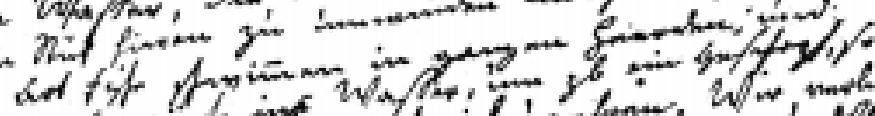

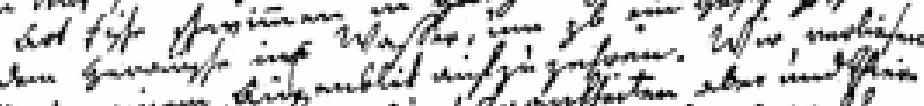

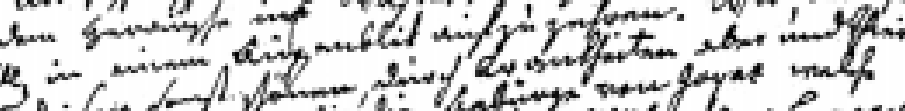

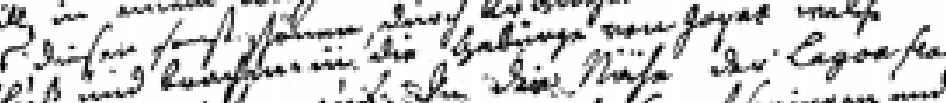

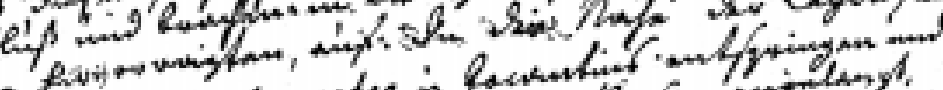

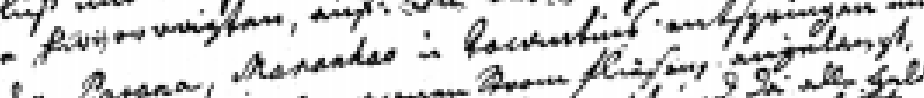

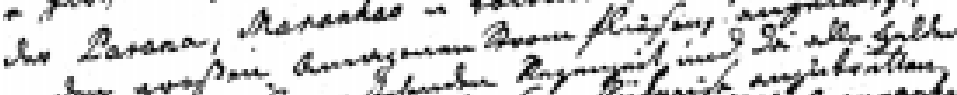

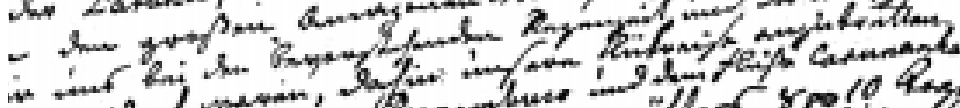
in

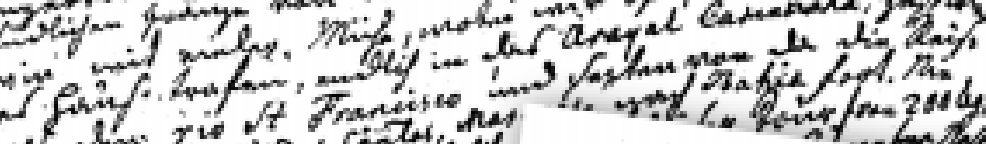

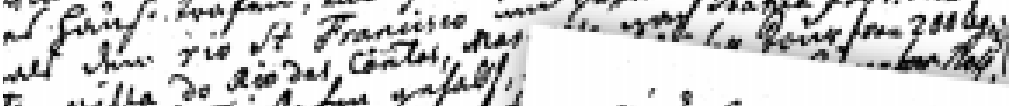

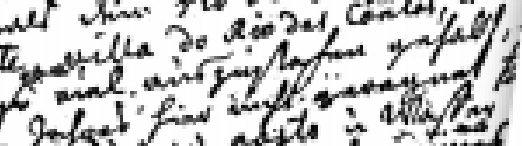

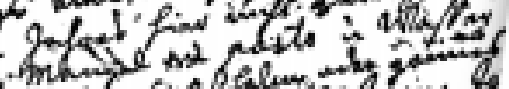

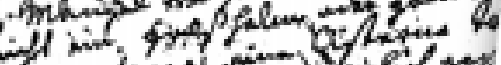

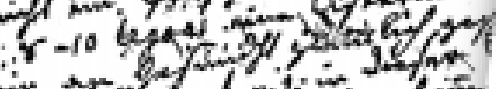

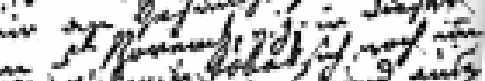

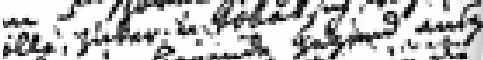
gin in

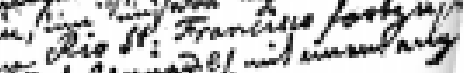

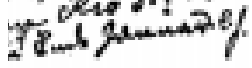

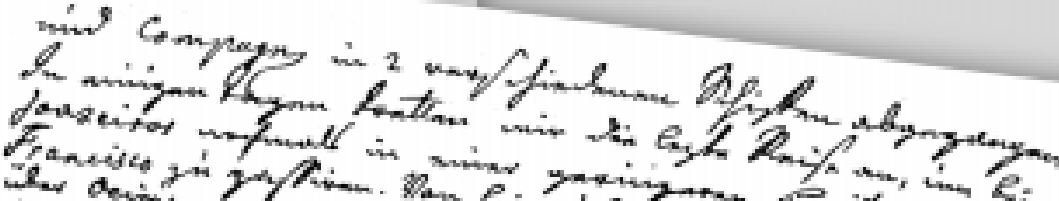
ind

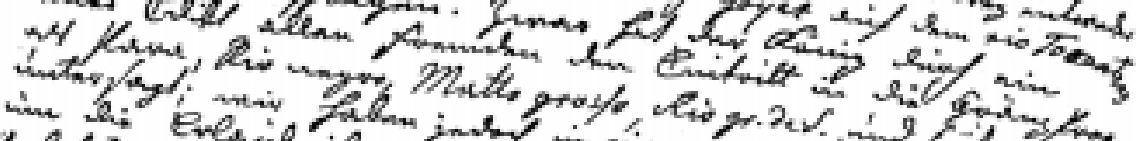

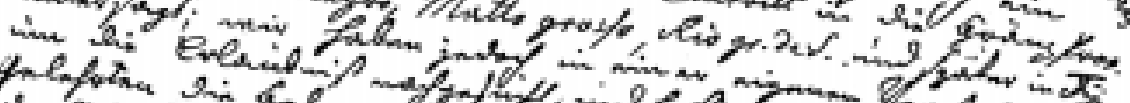

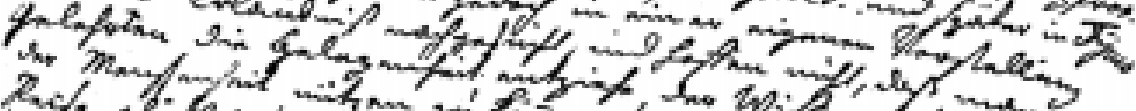

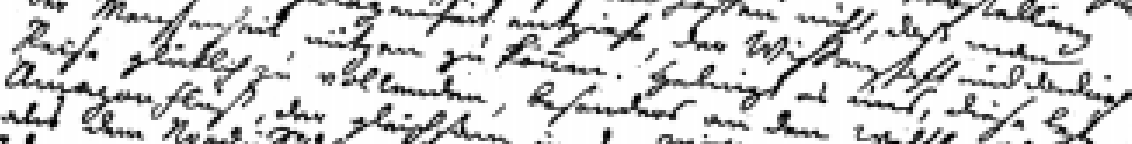

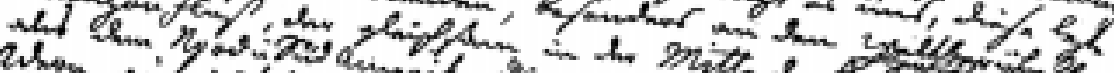

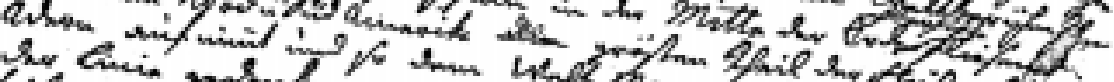

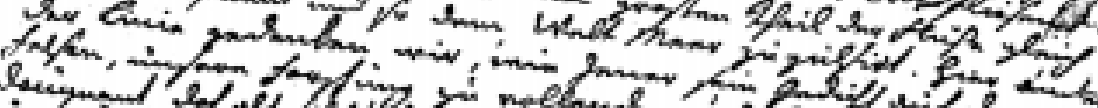

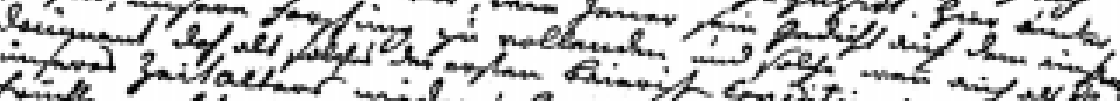

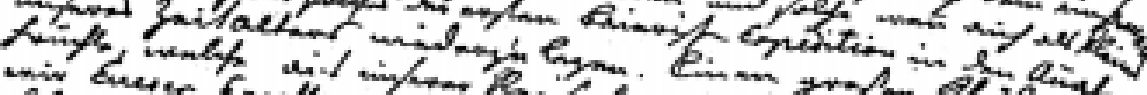

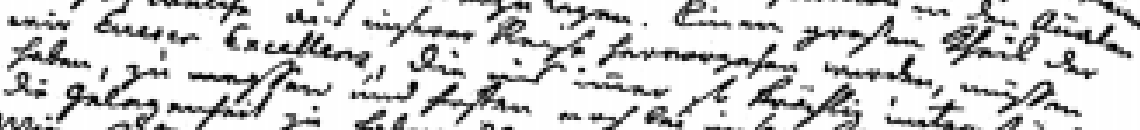
mond

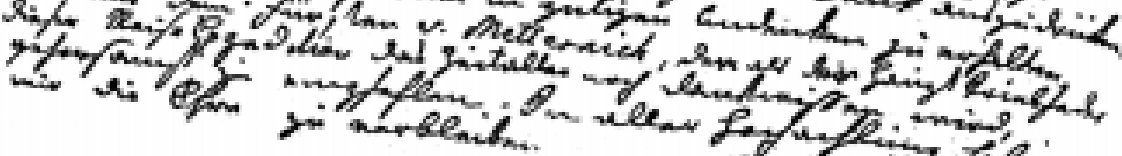

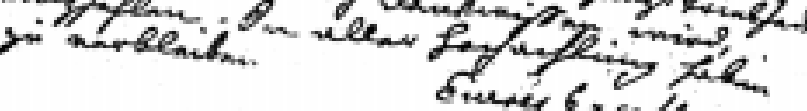

$$
\begin{aligned}
& \text { nivecuen. }
\end{aligned}
$$

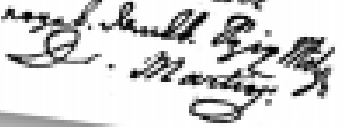


DEPOIMENTO

que, aos milhares, marcham como que alinhados numa ordem de batalha através das lagoas já bem ressecadas, e assim pescam em harmonia; os crocodilos nadam em bandos de 100, despreocupados, com a cabeça à flor da água, espreitando continuamente o gado sedento para apanhar e devorar um bocado dele; as piranhas, que são um tipo de peixe, nadam em cardumes, e aparecem ruidosamente na água, para, por exemplo, consumir num instante alguma criatura que queira atravessar a nado. No dia $1^{\circ}$ de junho, deixamos este rio em geral belo, mas horrível pelas doenças e animais, e partimos para as montanhas de Goiás que despontavam à distância. Chegando nas proximidades de Lagoa Feia, da qual surgem o Paraná, Maranhão e Tocantins a correr para o Pará rumo à grande corrente do Amazonas, decidimos iniciar viagem de volta à Bahia, pois a época das chuvas se avizinhava e tendo em vista que todo o dinheiro havia sido mandado para lá. Bordejando a fronteira sul de Pernambuco e o rio Carunanha chegamos, com muito esforço, ao Arraial Carinnaha, e durante esse trajeto ficamos freqüentemente de 8 a 10 dias sem ver uma única casa. Atravessamos novamente o rio São Francisco, e prosseguimos viagem para a Bahia por Caethete, Villa do Rio das Contas, Maracas. Nunca tivéramos de suportar tantos rigores quanto nesta jornada de 200 léguas, em vista de não ter chovido aqui no ano passado; o flagelo da fome foi então muito grande, a falta de pasto e água foi tanta que tudo estorricava, não se podia ver nem mesmo um talo de grama ou uma folha verde, e ficávamos contentes ao achar, a cada 8 - 10 léguas, uma cisterna com água turva. Assim, com nossa saúde enfraquecida e com a perda de alguns animais de carga, chegamos no dia 5 de novembro deste ano a esta cidade que ainda continua a enriquecer com o comércio de algodão, açúcar e tabaco. Desde então, estivemos inspeccionando a região circundante, fizemos uma excursão a Ilhéus, 30 léguas ao sul, e agora aguardamos os florins bávaros chegados ao Rio Janeiro em abril deste ano, via Londres, obsequiosamente enviados pelo senhor barão v. Neven, para realizarmos nossa última viagem por Oeiras para o Maranhão ou Pará, pelo rio São Francisco. Os nossos tesouros recolhidos desde Villa Rica - 12 caixas - partiram no final de janeiro deste ano rumo a uma embarcação inglesa em Hamburgo, destinados a $\mathrm{H}$. Schroeter e Compania, em 2 diferentes navios. Em alguns dias iniciaremos a última viagem para, em Joazeiros, novamente num estreito, atravessarmos o rio São Francisco. Daí tomaremos o caminho, ou por Oeiras para o Maranhão, ou através de Goiás pelo rio Tocantins rumo ao Pará. É certo que o Rei, num novo édito, proibiu a entrada a todos os estrangeiros na grã-província do Pará, Rio Negro, Matto Grosso, Rio Grande do Sul e mais tarde no Tijuco; mas nós solicitamos a permissão de moto próprio, e esperamos que não se tire de sábios a oportunidade de poderem ser úteis à ciência, e com isso à humanidade, se conseguirmos ter a felicidade de completar esta 
última viagem, especialmente pelo mundialmente famoso rio Amazonas, que parece correr no meio da superfície terrestre, recebendo, como veias, a maior parte dos rios da América do Norte e do Sul, atraindo, assim, o mar do mundo para si; aqui, sob a linha, como aquele que sobre a rocha solitária escreve sua poesia, tencionamos concluir nossa pesquisa e registrá-la novamente em um pequeno documento, como resultado da primeira expedição bávara nos anais de nossa era. Grande parte dos frutos que advirão de nossa viagem devemos a Vossa Excelência, que sempre nos apoiou decididamente, e, após o nosso retorno, esperamos ter com o a oportunidade de expressar o nosso agradecimento. Pedimos ademais que nos guardem com bondosa recordação, e que nos recomendem, o mais submissos, ao Príncipe v. Metternich, ao qual a época atual saberá agradecer o fato de ter sido a principal mola propulsora desta expedição. Com a mais alta consideração, temos a honra de nos subscrevermos

a Vossa Excelência Atencioso e obrigado Spix

Membro Dr. Martius. 


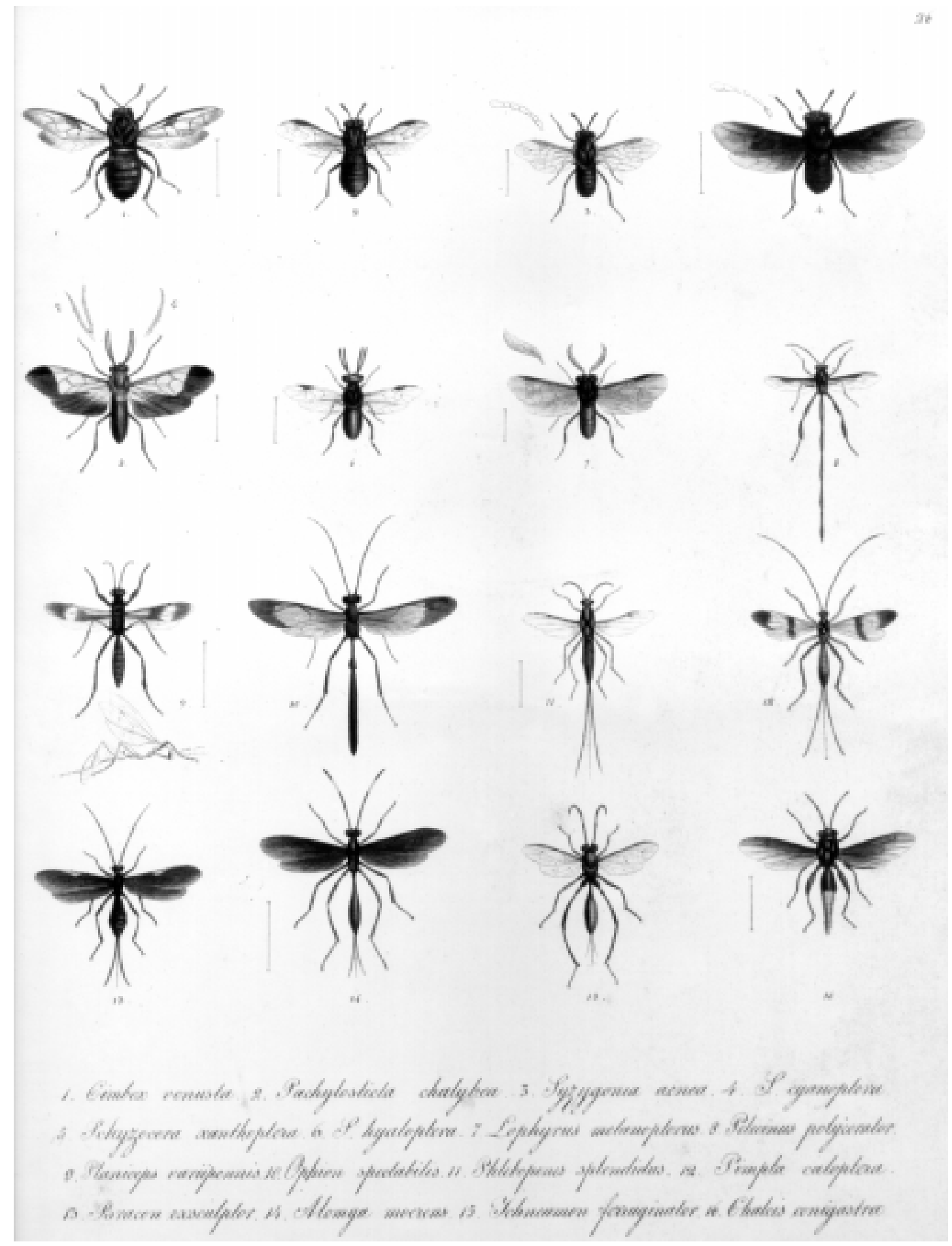

Spix, Johann Baptist von et Martius, Karl Friedrich Philipp von. Delectus animalium articulatorum, quae in itinere per Brasiliam annis 1817-1820. Monachii: Imprensis, 1830-1834.

Acervo da Biblioteca de Manguinhos/Fiocruz 
DEPOIMENTO
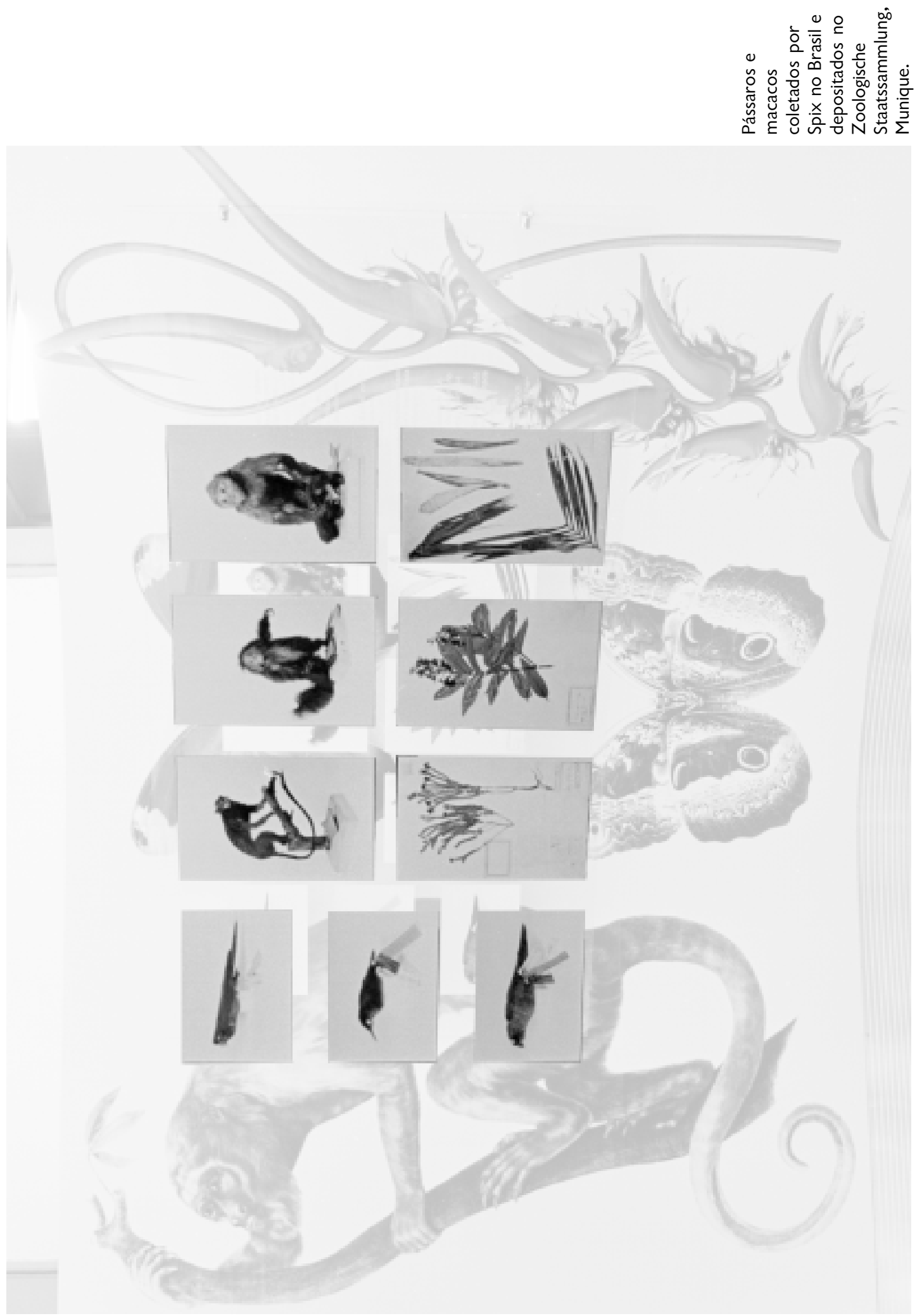
DEPOIMENTO

\section{REFERÊNCIAS BIBLIOGRÁFICAS}

Anônimo

1839

Hershkovitz, P.

1977

Lisboa, Karen Macknow

1997

Pacheco, J. F.

e Bauer, C.

1995

Perty, J. A. M.

1830-1834

Sick, $\mathrm{H}$.

1983

Spix, J. B. e

Wagner, J. A.

1827

Spix, J. B.

Spix, J. B.

$1824 a$

Spix, J. B.

$1824 b$

Spix, J. B. e

Agassiz, L. R.

$1829-1831$

Spix, J. B. e

Wagler, J. G.

$1824 \mathrm{C}$

Spix, J. B.

1823

Spix, J. B. Von.

1821
'Johann Baptist v. Spix. Eine biographische Skizze'. Vaterländisches Magazin für Belebrung, Nutzen und Unterhaltung, insbesondere zur Beförderung der Vaterlandskunde. Munique, Kunst und Industrie, pp. 15: 117-20.

Living New World monkeys. Chicago/Londres, The University of Chicago Press.

A nova Atlântida de Spix e Martius: natureza e civilização na viagem pelo Brasil (1817-1820). São Paulo, Hucitec/Fapesp.

'Adolf Schneider (1881-1946)'.

Atualidades ornitológicas, no 65, pp. 10-3.

Delectus animalium articulatorum, quae in itinere per Brasiliam annis MDCCCXVII-MDCCCXX jussu et auspiciis Maximiliani Josephi I. Bavariae Regis Augustissimi peracto collegerunt dr.J. B. de Spix et dr. C. F. Ph. de Martius. Munique. Fol. Fasc. 1, 1831, fasc. 2, 1832, fasc. 3, 1833.

'Die Bedeuteung von Johann Baptist von Spix für die erforschung der vogelwelt brasiliens', Festschrift zu ehren von dr. Johann Baptist Ritter von Spix. Spixiana, Supplement 9, Zoologische Staatssammlung München, pp. 29-31.

Testacea fluviatilia Brasiliensia. Munique, Herausgeber Dr. F. A Paul von Schrank und Dr. C. F. P. von Martius. 36 S., 29 Tafeln.

Animalia nova sive species novae lacertarum, quas in itinere per Brasiliam annis MDCCCXVII-MDCCCXX jussu et auspiciis Maximiliani Josephi I Bavariae Regis suscepto collegit et descripsit. Monachii, Typis Francisci Seraphi Hyschmanni, pp. 1-26, 28 Taf.

Animalia nova sive species novae testudinum et ranarum, quas in itinere per Brasiliam annis MDCCCXVII-MDCCCXX jussu et auspiciis Maximiliani Josephi I Bavariae Regis suscepto collegit et descripsit. Monachii, Typis Francisci Seraphi Hybschmanni, pp. 1-29, 22 Taf.

Avium species novae, quas in itinere per Brasiliam annis MDCCCXVIIMDCCCXX jussu et auspiciis Maximiliani Josephi I Bavariae Regis suscepto collegit et descripsit. Monachii, Typis Francisci Seraphi Hybschmanni, I, pp. 1-90, 91 Taf.; tom. II, pp. 1-85, 109 Taf.

Selecta genera et species piscium quos in itinere per Brasiliam annis MDCCCXVII-MDCCCXX jussu et auspiciis Maximiliani Josephi I. Bavariae regis augustissimi peracto colleget et pingendos curavit dr.J. B. de Spix, ... digessit, descripit et observationibus anatomicus illustravit dr. L. Agassiz, praefatus est et edidit itineris socius dr. F. C. Ph. de Martius. Monachii, I-xvii + i-ii +138 pp., 101 pls.

Serpentum Brasiliensium species novae ou histoire naturelle des espèces nouvelles de serpens recueillies et observées pendant le voyage dans l'ntérieur du Brésil dans les années 1817, 1818, 1819, 1820. Monachii, Typis Francisci Seraphi Hybschmanni, pp. 1-75, 26 Taf.

Simiarum et vespertilionum Brasiliensium species novae ou bistoire naturelle des espéces nouvelles des singes et de chauves-souris observées et recueillies pendant le voyage dans l'intérieur du Brésil. Monachii, Typis Francisci Seraphi Hybschmanni, I-VIII, pp. 1-72, 28 Taf.

Brasilien in seiner Entwicklung seit der Entdeckung bis auf unsere Zeit. Munique, Eine Rede zur Feyer des Maximilians/Tages. Denkschr. D. Kgl. Akad. D. Wiss. pp. $1-44$. 
Spix, J. von 1811

Spix, J. Von. 1814b

Spix, J. Von. $1814 a$

Spix, J. Von. 1815

Spix, Johann Baptist von e Wagler, Johann Georg 1981

Vanzolini, P. E. 1981

von Spix, Johann Baptist Ritter e von Martius, Karl Friedrich Philipp 1823

Wied-Neuwied, M. 1825-32

Wied-Neuwied, $M$. 1822

Wied-Neuwied, $M$. 1820-1821

Wilson, Edward O. 1999
Geschichte und beurtheilung aller systeme in der zoologie nach ihrer Entwichlungsfolge von Aristoteles bis auf die gegenwärtige Zeit. Nuremberg, Schrag'sche Beuchhandung, I-XIV.

'Abhandlung über die Affen der alten und der neuen Welt im Allgemeinen, insbesondere über den schwarzen Heulaffen (Simia belzebul Linné) und über den Molch (Simia Moloch Hofmannsegg) nebst den Abbildungen der beiden Letzten und einem Verzeichnis aller bis jetzt bekannten Affenarten'. Denkschr. D. Kgl. Akad. d. Wiss. Munique, pp. 321-42.

'Darstellung des gesamten inneren Körperbaues des gemeinen Blutgiels (Hirudo medicinalis Linné)'. Denkschr. D. Kgl. Akad.d. Wiss. Munique, pp. $182-224$

Cephalogenesis sive capitis ossei structura, formatio et significatio per omnes animalium classes, familias, genera ac aetates digesta, atque tabulis illustrata, legesque simul psychologiae, cranioscopiae ac physiognomiae inde derivatae. Monachii, Typis Francisci Seraphici Hübschmanni, 11u 72pp.

Herpetology of Brazil. Introdução de P. E. Vanzolini, .Kansas, Society for the Study of Amphibians and Reptiles

The scientific and political contexts of the Bavarian expedition to Brazil. Em J. B. von Spix, e J. G. Wagler, Herpetology of Brazil. Reprinted, Society for the Study of Amphibians and Reptiles.

Reise in Brasilien auf Befehl Sr. Majestät Maximilian Joseph I König von Baiern in den Jabren 1817-1820. Munique, M. Lindauer, theil 1-3, 412 pp.

Beiträge zur Naturgeschichte von Brasilien.

Weimar, 5 vols.

Kupfer und Karten.

Frankfurt $\stackrel{a}{M}$.

Reise nach Brasilien in den Jabren 1815 bis 1817. Frankfurt, Heinrich Ludwig Bronner. 2 vols.

A unidade do conbecimento: consiliência. Campus, Rio de Janeiro. 